\title{
The Triune God who speaks: Calvin's theological hermeneutics
}

\author{
James B. Krohn \\ Department of Systematic and Historical Theology \\ The Bible Institute of South Africa \\ KALK BAY \\ E-mail: krohn@new.co.za
}

\begin{abstract}
:
The Triune God who speaks: Calvin's theological hermeneutics

The purpose of this article is to make a contribution to the theme of "Calvin as servant of the Word" by exploring some hermeneutical implications of Calvin's theological commitment to the doctrine of God as Triune. In doing so, it seeks to follow a hermeneutical principle Calvin himself held, that Biblical interpretation had to pass through three distinct but related phases; exegesis (represented by his commentaries), dogmatics (represented by the Institutes), and preaching (represented by his sermons). For Calvin, if any of these phases were omitted, the text would not be interpreted properly, and the message of Scripture would not rightly be applied to the life of the church. The place and importance of the doctrine of the Trinity in Calvin's theology (often neglected in Calvin scholarship) are first explored, followed by displaying the importance Calvin attached to the integration of doctrine into the hermeneutical process (often disregarded by modern-day exegetes), and finally, all three phases of the interpretational process are brought to bear on Calvin's sermonic treatment of John 1:1-5. Through expository preaching of the Scriptures, hermeneutics finds its completion, and believers will have a personal encounter with God. As such, Calvin will be shown to be a most excellent servant of the Word.
\end{abstract}

\section{Introduction}

For as God alone is a fit witness of Himself in his Word, so also the Word will not find acceptance in human hearts before it is sealed by the inward testimony of the Spirit (Calvin, Inst. 1.7.4). 
Since the triune God - the Father and the Son, through the Spirit already preaches to us in every part of the Bible, the human preacher's task resolves into becoming a mouthpiece and sounding board for the divine message that meets him in the text (Packer, 1996:124).

For, among the many excellent gifts with which God has adorned the human race, it is a singular privilege that he deigns to consecrate to himself the mouths and tongues of men in order that his voice may resound in them (Inst. 4.1.5).

In a letter presumably written around October 1548 to Edward Seymour, Duke of Somerset, John Calvin somewhat surprisingly staked the entire success of the achievement of an open and complete reformation of the church in England on preaching. He stated:

There is some danger that you may see no great profit from all the reformation which you shall have brought about, however sound and godly it may have been, unless this powerful instrument of preaching be developed more and more. ... The edicts and statutes of princes are good helps for advancing and upholding the state of Christianity, yet God is pleased to declare His sovereign power by this spiritual sword of His Word, when it is made known by the pastors (Calvin, 1980:96).

The primary qualification was not only that the preaching was to be "lively" and the preachers "good trumpets," but that there was to be "an explicit summary of the doctrine which all ought to preach, and which all prelates and curates swear to follow" (Calvin, 1980:95). No one was to be committed to an ecclesiastic position and who did not promise to uphold such agreement, so that sound doctrine and the preaching thereof constituted the conditio sine qua non of reformation. In Geneva, besides the doctrinal (instructional) impact of the Institutes, Calvin's own manner of influence was essentially exercised through preaching. The context in which these activities of Calvin took place nevertheless had a profound effect on his theologising and his stature as a theologian. No less than for his German predecessor, Luther, the fabric of Calvin's maturing theology was woven through with trial and affliction and it was tentatio which moulded him into a true theologian.

John Calvin was, however, called "the theologian" for another reason. Torrance (cf. 1994:21) suggests that this distinction was given to him, as it was to Gregory of Nazianzen in the fourth century, because he (like Gregory) exemplified a deep grasp of the Trinity and rigorously defended the doctrine. As the Protestant struggle in Geneva was inseparable from Calvin as its protagonist, those who desired to strike a damaging blow at the reformed cause could hope for no better than discrediting his Catholic orthodoxy. And, as there was clearly no doctrine of higher orthodox priority than the Nicene-Trinitarian doctrine of God, it is no 
surprise that virtually from the moment he set foot in Geneva, and in fact for the remainder of his life, Calvin found himself drawn to combat in this doctrinal arena (cf. De Greef, 1993:46,1 71-81; Butin, 1995:29-38). He was obligated to battle anti-trinitarians such as Caroli (1537), Courtois (1543), Servetus (1545-53), and Castellio (1545 onwards), as well as the Italian anti-Nicenes (Gribaldi, 1555; Blandrata, 1558; and Gentilis, 1558) and Polish Unitarians (such as Stancaro, 1560) in the 1550's to 1560's. He was even drawn into theological debate with Menno Simons via Martin Micron (1558) on Menno's conception of the incarnation, and after his death, the battle did not subside, but continued and intensified (Rotondò, 1968:2-10). There is no doubt that these conflicts had a concentrated impact on Calvin, and forced him to expound more thoroughly on his doctrine of the Trinity. This is reflected in the Institutio, in the Commentaries and in his sermons. Indeed, among Calvin's attempts to integrate doctrine into churchly and Christian life, few play as significant a role as his doctrine of the Trinity. It is this doctrine which gave structure to his theological framework, and subsequently impacted his hermeneutics.

\section{Calvin's trinitarianism}

It has often been remarked that there is nothing unusual or new about Calvin's doctrine of the Trinity. This is true only insofar as we consider his view to be in accordance with Nicene orthodoxy. Under closer inspection one discovers with B.B. Warfield, that Calvin's sharp insistence on the full co-equality of the three Persons in the Godhead "marks an epoch in the history of the doctrine of the Trinity" (Warfield, 1956:283). This (primarily exegetical) insistence on each Person being autotheos, a distinction of Cappadocian (Eastern) theology, coupled with Calvin's acknowledged indebtedness to Augustine (Western theology), makes his exposition in the Institutio (cf. 1.13.5) an axiom of historical theology (Bray, 1993:156). The fact that the one true God is actually and intrinsically Triune, has many implications, not least for our knowledge of and interaction with God.

A renewed look at Calvin's trinitarian understanding of the divine-human relationship came along with the remarkable transformation his image has undergone this last century. No longer is he held to have predominantly fashioned a deterministic predestinarian theology starting from eternal decree rather than Scripture, but is now increasingly appreciated for being a biblical (rhetorical), rather than a philosophical (rationalistic) theologian (Partee, 1987; McGrath, 1990; Butin, 1995). There are subsequently several important points to make with regard to Calvin's trinitarianism. 
- First, note the prominence of the doctrine of the Trinity in the structural development of the Institutio. In the 1536 edition, only one of the total of six chapters dealt with the Creed which would have suggested Nicene orthodoxy. As a result of the Caroli controversy (Feb. 1537), in which Calvin and Farel were accused of Arianism and for not using the old formulas, Calvin greatly developed his Trinity doctrine in the second edition (1539). The pattern of the later editions from here onward was shaped by the Creed. Book One corresponds to Credo in Deum; Book Two, Et in lesum Christum; Book Three, Credo in Spiritum sanctum; and Book Four, Sanctum ecclesiam catholicam. The new form and pattern of the Institutio, though its content was not a direct exposition of the Creed, suggested a claim by Calvin that its teaching was an authentic statement of the faith of the one, holy, catholic and apostolic church. Moreover, its arrangement reflected Calvin's desire that he wanted his theology to be read in this trinitarian way (cf. Parker, 1995:4-10).

- Second, underlying the structural development of the Institutio, was Calvin's faithfulness to the Scriptural witness. This exegetical priority committed him thoroughly to trinitarian doctrine (cf. 1.13). As a result, he overcame an initial reluctance to use Patristic terminology and developed a committed (though discerning) stance toward the early Catholic creeds and the theological language of the church. Calvin defended its use not simply because it was orthodox tradition, but because it was biblical. "What wickedness it is," he said in reference to the objection by his opponents to the use of trinitas and persona, "to disapprove of words that explain nothing else than what is attested and sealed in Scripture" (1.13.3). From the earliest versions of the Institutio Calvin expressed that "quarrelling over words" would bring a loss of truth, and was thus committed to defending the biblical truth guarded by the terminology (cf. 1536 Inst., 2.8; see Calvin, 1975).

- Third, it is well-known that Calvin was not interested in the philosophical ruminations of abstract theology. The importance he attached to trinitarian doctrine was for a very different reason. In the 1559 Institutio, we find that most of 1.13 (on the Trinity) is devoted to a defence of Christ's deity. In Calvin's mind, as at Nicea, the homoousios of the Son with the Father was the foundation of the doctrine of the Trinity. The doctrine was therefore crucial, because it safeguarded the deity of the Word and thus the priority of salvation secured in him. George (1988:200 f.) states that "the purpose of Calvin's trinitarianism was, like that of Athanasius, soteriological. He wanted to safeguard the biblical message, 'God is manifest in the flesh', against false interpretations". Anti-trinitarians were not attacking catholic Chris- 
tianity as an institution, but salvation itself (cf. Clark, 1999:24). Calvin's emphasis is therefore also on the economic Trinity, "God-asGod-is-towards-us", that is, on God's external operations as detected by the distinct roles which each of the divine persons played in the history of redemption (cf. 1.13.17-20). Though he does engage in some intra-trinitarian discussion (cf. 1.13.25), he was determined not to lapse into scholastic speculation and, for example, rebuked those who pursued the question of eternal generation when "it is clear that three persons have subsisted in God from eternity" (1.13.29).

- Fourth, it follows that Calvin's conception of God is nearly always conditioned by the Trinity. We may well note that the Institutio contains no "doctrine of God" (of essence or attributes) in the medieval scholastic (or Protestant orthodox; cf. Lane 1991:23f) sense, other than the doctrine of the Trinity (cf. 1.13.20). To know God as Triune, is to know the true God. As Calvin stated; "that passage in Gregory of Nazianzus vastly delights me: 'I cannot think on the one without quickly being encircled by the splendour of the three; nor can I discern the three without being straightway carried back to the one"' [On Holy Baptism, oration xl. 41] (1.13.17). It also follows that his defence of the uniqueness of Christianity over against other religions ("True God from False Gods"; 1.14), is subordinated to and flows from his treatment of the Trinity. Even rival versions of Christianity stand or fall on this doctrine; "not all the articles of true doctrine are of the same sort. Some are so necessary to know that they should be certain and unquestioned by all men as the proper principles of religion. Such are: God is one; Christ is God and the Son of God; [and] our salvation rests in God's mercy" (4.1.12). For Calvin, "the ground of all heresy" was denying the witness of the Word that God is Father, Son and Spirit (1.13.21).

- Fifth, the "mystery of the activity of the Triune God constitutes the comprehensive systematic framework of what Calvin says about God's will for salvation, and especially of the unfolding of his will in history" (Ganoczy, 1989:96). The reality and efficacy of grace is thus the common work of the Trinity, and Calvin's economic-trinitarian emphasis allowed for a "spreading" of the doctrine throughout the four books of the Institutio. This is evidenced in the development of its structure (cf. Neuser, 1984:50), and is especially true in terms of the work of the Holy Spirit which came to take up the themes of books 3 and 4 (cf. Hesselink, 1997:177-187). Subscribing faith, regeneration, the church and the sacraments to the work of the Spirit allowed Calvin to resolve a number of difficulties held between opposing reforming parties (cf. Butin, 1995:107-121). Similarly, it removed the antithesis 
between objectivism and subjectivism in connecting the doctrines of justification and sanctification with the Christian life. Christian life itself was now understood on the basis of "the insertion of the believer in Christ" (insitio in Christium), a trinitarian operation. Again, difficulties held between Luther, Melanchthon and Zwingli, and which composed somewhat of a "structural defect" in early Protestantism, were resolved.

By treating these two elements [justification and sanctification], which had hitherto been regarded as independent entities requiring correlation, as subordinate to the believer's union with Christ, Calvin [was] able to uphold both the total gratuitousness of our acceptance before God and the subsequent demands of obedience placed upon us (McGrath, 1990:166).

Calvin was thus able to resolve these key methodological questions, because "his soteriology was the product of a more highly developed and theologically integrated doctrine of the Trinity" (Clark, 1999:24).

- Finally, however, the issue at stake was not the intellectual resolve of theological questions, but living a life of faith. The Trinity was not an esoterical doctrine for Calvin, but central to the Christian faith and closely connected with one's spirituality. Houston (1996:236) aptly remarks:

[For Calvin] the self-revelatory character of God in his triune Being has opened up for us a way of communion with himself that is the source of ceaseless worship and of meditation upon his Word, through his Spirit. Indeed, we can say that the greatest impact made upon the Christianisation of the world of the fourth century, as upon the sixteenth century, is the recovery of the doctrine of the Trinity.

In conclusion, we may say that the doctrine of the Trinity allowed Calvin a certain structural justification for the revision of Protestant theology in accordance with Catholic orthodoxy. It also gave him a biblical basis for his theological framework, and subsequently (as we shall see below), a theological vision (the application of the framework) with which to understand the individual's place within the unfolding redemptive activity of the Triune God in history. Calvin's trinitarianism is manifest of his primary regard for the biblical message that "to the Father is attributed the beginning of activity, and the fountain and wellspring of all things; to the Son, wisdom, counsel, and the ordered disposition of all things; [and] to the Spirit is assigned the power and efficacy of that activity" (1.13.18). That his trinitarian-redemptive-historical understanding of the biblical message would have impacted his exegetical conclusions, is to be expected. 


\section{Integrating theology and exegesis}

As the sixteenth century was above all things "the age of the Bible" (Parker, 1971:vii), it is not coincidental that a wave of reaction rose against the often unbiblical character of much Medieval dogmatic concurrence. But, even as sola scriptura established itself as the primary basis for arriving at doctrine among Reformers, the question arose of how biblical exegesis was to be organised into a coherent and comprehensive theology (cf. Parker, 1971:26 f.). Calvin's achievement stands out in this regard, and so the question of his theological method is important (cf. Gamble, 1988a:178-94), as is the correlation of the Commentaries with the Institutes (cf. McKee, 1989:154-72). However, Calvin's theological reading of the biblical text is sometimes overlooked, and the way in which it impacted his hermeneutics should be explored.

\subsection{The Theo-logical dimension of hermeneutics}

Theology is a text-centred science, and doctrine is formulated as the result of a centuries-long process of biblical interpretation. Therefore, to speak of biblical authority outside of biblical interpretation is inconceivable (cf. McGrath, 1993:134-158). In other words, theology has a strong interpretative dimension. What is, however, very commonly neglected or negated, is that interpretation has an equally important theological dimension (cf. "Augustinian Hermeneutics" in Vanhoozer, 1998:29-32). All search for understanding is inherently theo-logical. There is a God-dimension, a hankering after Him, in all human quests. Calvin demonstrated this superbly in the Institutio by stating from the outset that the sum of all wisdom (sacred doctrine in the 1536 Inst.) lies in knowing God and knowing self, and that "all men are born and live to the end that they may know God" (cf. 1.1.1-3). The thematic importance of this declaration for the whole of the Institutio can hardly be overemphasised.

It follows that all hermeneutical schemes reflect underlying notions about God and humanity. The effects of erroneous notions of God on biblical interpretation are well documented in the annals of the church. In the late Middle Ages, theologia had the "being of God" as foundational principle, and was defined as sermo vel ratio de Deo; a word or rational discourse concerning God (Muller, 1991:45). Its goal (praxis), was the union of the believer with God. However, it was accepted among scholastic practitioners of theologia to have a philosophical rather than an expressly biblical notion of God occupying this position of epistemological privilege. The result was that when Luther presented his theologia crucis as a new paradigm for theologia, an upset was caused which saw epistemology put aside in favour of soteriology. Calvin on the other hand, was able to 
reprioritise the Person of God without forfeiting the newly gained emphasis on soteriology. He achieved this by means of the Trinity. Williams (1995:173) explains:

In the Institutes, biblical doctrine is organised in accordance with trinitarian belief, following the pattern of the Apostles' Creed. It begins and pursues its course with the epistemological question of the knowledge of God. But engagement with epistemology immediately reveals the tragedy of the human condition, so that we await in the Institutes the announcement of the gospel that will do something about humanity which has, by disobedience, forfeited a part of the knowledge of God and made what remains salvifically, impotent. It is with the discussion of Christ the Redeemer, in the second book of the Institutes, that the burden is lifted and dogmatics becomes Good News.

In this way, Calvin's theology was no less a theologia crucis than Luther's, the difference being that Calvin's exposition of sin and grace was conceived along distinctly trinitarian lines. The Trinity, not a philosophical conception of God, governed his hermeneutics.

\subsection{The benefits of theological commitment}

It has been pointed out by biblical interpreters that the notion of approaching a text without any theological predispositions, is at best naive. An intimate and complex connection exists between theology and exegesis, and interpretation neither begins nor ends with exegesis. "Good" hermeneutics must necessarily demonstrate exegetical and theological integration, and Calvin's writings are a fine example of this. During the course of more than two decades (the Institutes span from 1536 to 1559, the period in which most of the Commentaries were also written), his theological thought guided his exegesis, while his exegesis continued to contribute to his theology (cf. Silva, 1994:251). Though the exegetical method practised in the Commentaries was not identical to that used in the Institutes, the relationship between the two was self-consciously symbiotic (cf. Epistle to the Reader, 1559 Inst.). Both his expositions and his theology were superb exactly because they were related. Bray (1996: 177) states that "Calvin is the one Reformer whose commentaries still stand in comparison with what is produced today, and in a real sense he may be called the father of modern biblical scholarship. His output was overwhelmingly biblical, [even] though it was anchored in ... the Institutes". It is this coherence as an exegete which contributed to the impact he made on the biblically oriented world of the sixteenth century. Even so, it would appear from a study of the use of biblical citations, that Calvin's particular genius lay in his theological perspective on exegesis (cf. McKee, 1989:168). 
Silva (1994) has ably shown that Calvin's prior theological commitments were (from a hermeneutical standpoint) both desirable and essential. Two examples will suffice to make the point; the assurance of salvation as experienced by believers, and predestination and election. Firstly, in Book 3 of the Institutio, Calvin gives depth to our biblical understanding of the outworking of God's grace in Christ by means of a "trinitarian framework". Beeke (1999:55) summarises Calvin's argument:

The grace of faith is from the Father, in the Son, and through the Spirit, by which, in turn, the believer is brought into fellowship with the Son by the Spirit and consequently is reconciled to, and walks in fellowship with, the Father.

Secondly, the same applies to the doctrine of predestination and election which also appears in Book 3. Its very location in the Institutio of 1559 is significant, as it follows Calvin's exposition of (trinitarian) grace. Like the Trinity, it is not a doctrine based on speculation, but on divine revelation $(1.2 .2 ; 3.21 .1-2)$. To claim that predestination is the central premise of Calvin's theological "system" (an inappropriate term in any case), is far from accurate (cf. McGrath, 1990:169). Calvin's positioning of this doctrine has been governed not by an abstract or capricious notion of God, but by a God who draws near to us in the economy of redemption. Throughout the Institutes, Calvin's theological perspective on hermeneutics gave clarity to his biblical and theological exposition.

\subsection{Biblical-theological hermeneutics}

The integration of theology and exegesis had another benefit, that of keeping theological unity and historical progression together in the Scriptures, and again the doctrine of the Trinity had a role to play. Calvin did not entertain the methodological polarity modern-day scholars posit between theology and biblical studies. To him it was all biblical theology, and by integrating the continuous-expository method of the Commentaries with the topical-expository method of the Institutes, he attempted to provide the biblical foundation necessary for the Reformation programme (Parker, 1971:26-48). The resulting redemptive-historical or biblicaltheological approach which Calvin's efforts gave rise to (e.g. covenant theology; cf. Bray, 1996:204-8), achieved recognition for the unitary message of a Bible given in two Testaments.

Calvin valued that the Scriptures constituted a text with a developing story, and that redemption is an activity of God unfolding over time and in history. The division of the Institutes recognises this fact along with God's Triune activity in and through that history. Theology is not an abstract discussion of redemption, but of redemption in its historical matrix. More significantly, biblical history by God's own appointment, revealed God 
himself (cf. Lints, 1993:262-4). The fullness of God's self-revelation was in Christ (cf. John 1:18; Hebrews 1:1-3). Calvin was thus able to link redemptive history with a trinitarian doctrine of God. In both, the focus or structural locus was offered by Christ. Calvin could write as if the Jews knew and understood, albeit imperfectly, the doctrine of Christ (2.6.4), and, as he stated in his Commentary on John 5:39, "the Scriptures are to be read with the purpose of finding Christ there". Though he was thoroughly opposed to any unhistorical or allegorical reading of the text, Christ still represented the hermeneutical key to the Scriptures. The Incarnation gave fullest expression to God's gracious saving initiative in the Father revealing, the Son redeeming and the Spirit transforming his people (2.12-14).

The theocentric and holistic nature of the biblical-theological approach, by emphasising historical progression and theological unity in the Bible, offered many benefits for teaching and preaching (cf. Greidanus, 1988: 72; Clowney 1961:63-86). Not least, it opened up the biblical text beyond "scriptural proofs", and brought a deeper understanding of God's faithfulness in saving grace. Biblical-theological hermeneutics allowed Calvin to achieve "a balance between the text, its meaning and its application which has seldom if ever been equalled in the life of the church" (Bray, 1996:204).

\section{4. "In the beginning was the Speech ..." (John 1:1)}

As the preaching of the Word concludes the hermeneutical process for Calvin, it remains now to give an indication of how Calvin's trinitarian and biblical-theological emphasis is exemplified in a sermon. But first, a few comments on Calvin's use of the "Word of God".

\subsection{The Word of God (John 1:1)}

Calvin's use of the term Verbum Dei is fairly nuanced in his writings, and offers a range of meaning, from Scripture itself, to Christ (and preaching him), to the Spirit's testimony in the hearts of believers. The Protestant orthodox, drawing from Calvin (and the other Reformers), distinguished four basic and interrelated meanings of the term Verbum Dei (cf. Muller, 1985:324; Gamble, 1988b:63-75). First, it referred to the eternal Word of God, the Second Person of the Trinity, the Son; second, to the incarnate Word, Jesus Christ, the divine-human Mediator of salvation; third, to the inspired Word of the Holy Scripture, which is the Wisdom of God given in a form accessible to man; and fourth, to the internal Word of the Spirit, which testifies to the human heart concerning the truth of the written or external Word. All these meanings, somewhere or other, can be traced to 
Calvin. Note however, what Calvin says of the Logos of John 1:1 specifically:

John spoke most clearly of all when he declared that that Word, God from the beginning with God, was at the same time the cause of all things, together with God the Father [John 1:1-3]. For John at once attributes to the Word a solid and abiding essence, and ascribes something uniquely His own, and clearly shows how God, by speaking, was Creator of the universe. Therefore, inasmuch as all divinely uttered revelations are correctly designated by the term 'word of God', so this substantial Word is properly placed at the highest level, as the wellspring of all oracles. Unchangeable, the Word abides everlastingly one and the same with God, and is God himself (1.13.7).

The Word (Logos) has a trinitarian and revelatory (also governing; cf. Heb. 1:3) association, and both are soteriologically oriented within the context of John 1. John 1:1 f.f. is thus an important passage from a biblical-theological and trinitarian perspective, as by clear allusion to Genesis 1:1 f.f., a link is established between Creation and Redemption and between Creator and Redeemer.

\subsection{Sermon on the deity of Christ (John 1:1-5) ${ }^{1}$}

The sermon (or lecture) used in this article to exemplify Calvin's hermeneutical traits, comes from the collection Plusieurs sermons de lehan Calvin touchant la divinité, humanité, et nativité de nostre Seigneur lésus Christ, and is entitled "The Deity [divinité] of Jesus Christ" (1550). Note that Calvin's first sustained exegetical encounter with the Gospel of John occurred shortly after his appointment as Lecturer in New Testament Interpretation (February 1539) at the Gymnasium in Strasbourg, but that it was not until 1553 that his Commentary on John appeared (cf. De Greef, 1993:107,117-8). The sermon, much like its counterpart in commentary (material was usually supplied from the one to the other), is introduced with an explanation of the word "Gospel," though notably for the sake of the audience, its description was made explicit and repetitive. Note the redemptive-historical focus on Christ and on God's fatherhood (a consciously trinitarian move):

The word 'Gospel' indicates that God in sending our Lord Jesus Christ His Son declares Himself Father to all the world (Sermon, 1.10). ... The Ancient Fathers ... were well assured that God would be their Father ... when Jesus Christ came into the world, God signed and sealed His fatherly love (Sermon, 1.11). 
Interestingly, Calvin saw John as holding "the key to understanding the other Gospels" (Sermon, 1.12). In the "argument" to his Commentary on John, Calvin had stated that Matthew, Mark and Luke exhibited Christ's body, but that John exhibited his soul. The reason was that in John, Christ's Deity (the keystone of trinitarian doctrine) and the virtues which come from his office were superbly demonstrated. John thus taught us "more" about Jesus than discovered elsewhere. Calvin's ensuing comments on the Word (John 1:1), is similar to his discussion of the Trinity in the Institutes (1.137). Christ is the eternal and the incarnate Word, for "He already was, from all time and before all time" (Sermon, 1.13), and, "St. John here wishes to show that when Jesus Christ came into the world, it was our Eternal God Who came, Who redeemed us to Himself" (Sermon, 1.14).

The Word is also "the Wisdom which was always in God" (the inspired Word), though John does not expound upon it, the Spirit accommodating himself to us ("since we are carnal He must stutter", Sermon, 1.14). This gives Calvin occasion to deplore the "foolish imagination, vain speculation, and diabolical audacity" of the Papacy and the Sophists who inquire into the eternal essence of God, "as if they were disputing about a flock of goats" (Sermon, 1.14-15). Calvin admonishes that there ought to be contentment with what the Holy Spirit has shown with regard to the "eternal plan of God" because "God's plan is really God", i.e., the Incarnation is the focus of God's historical redemption of mankind (Sermon, 1.15).

It is not surprising that Calvin includes in the sermon a full trinitarian defence against the Arian position of "there was a time when the Word was not", which he links with an intricate exposition of the meaning of "In the beginning ..." (John 1:1a). We must remember that he and Farel had been maliciously accused of Arianism, and if we take the exegetical origins of the sermon to come from the Strasbourg period, we should not be surprised by the extent to which trinitarian orthodoxy is sought and exemplified. "The Word was with God" (John 1:1b) and "the Word was God" (John 1:1c) similarly allowed him to employ the rudiments of his Christologically grounded formula, distinctio sed non separatio; the Word is distinct but not separate from the Father. Calvin even resorted to using theological terminology (like in the Institutio) in order to explain the distinction between God and His Word. One may well wonder how even a theologically educated congregation assimilated this information, though he does resort to simplify it to; "it is not improperly to say, 'God was with Himself'” (Sermon, 1.18). 
The high point of his discussion focuses on "an ancient teacher's [Gregory] sentence", which he recommends his audience to remember. Note the variation brought out in the French (cf. 1.13.7):

'I cannot think upon these three properties which are shown me in God unless immediately my mind reduces them to one. On the other hand, it is impossible for me to know one only God unless I regard all the three properties, and I see them distinguished by my sense according to the clarity that is given me in Holy Scripture'. That is how believers will know God. Knowing the Father, they will know His wisdom, which is this Word which is here spoken of. ... When they have known these three, they will no longer go astray ... they will come to his sole essence - to know that there is only one God [who] has omitted nothing of all that was required to accomplish our redemption (Sermon, 1.18; my emphasis - JBK)

It is hard to conceive of a more breathtaking passage to exhibit Calvin's trinitarian emphasis on a redemptive knowledge of God. Note also that his exposition includes Cappadocian and Augustinian trinitarian elements. His reason is simple: "... when we remember this exposition [of the Trinity], it will suffice to instruct us for our salvation. Surely it is all we need to know about it" (Sermon, 1.19). The sermon is also concluded with a (noticeably) trinitarian paragraph:

... it is only reasonable that we should learn to cling to this Word and to know in general, the benefits God has given to mankind, in order that the light ['clarity', Fr. clarte] He has poured upon us by His grace may not be extinguished by our wickedness, but that Jesus Christ may so dwell in the midst of us that, being led by the Holy Spirit, we may be able to have such access to the Father that He may introduce us into His heavenly glory (Sermon, 1.27; my emphasis - JBK).

It is not a surprise that in the sermon (which completes the hermeneutical process) Calvin follows the same trinitarian trajectory he took in Institutio and Commentary, and if anything, it is his theological perspective which dominates the exposition.

\subsection{The Word and divine communication}

In the closing section of the sermon we find an interesting statement by Calvin, which requires further comment:

Now I have treated things as briefly as was possible for me, always hoping to attain the object which was before the Gospel-writer. However, if I have omitted something because I could not remember everything, let each one of you say what God has revealed him about it (Sermon, 1.27; my emphasis - JBK). 
Calvin seems to suggest by "revealed" not only content (which he may have omitted), but also communication by God to the hearer. It parallels with what he has said about the witness of Scripture elsewhere: "For as God alone is a fit witness of Himself in his Word, so also the Word will not find acceptance in human hearts before it is sealed by the inward testimony of the Spirit" (1.7.4). It is not without reason that Calvin translates Logos into Speech. The definitive Word - Christ, is mediated via the Spirit (cf. Sermon, 1.27), as is the verbal Word - Scripture, and the preaching thereof:

Nothing is accomplished by preaching [Christ] if the Spirit, as our inner teacher, does not show our minds the way. Only those men, therefore, who have heard and have been taught by the Father come to him. What kind of learning and hearing is this? Surely, where the Spirit by a wonderful and singular power forms our ears to hear and our minds to understand (2.2.20).

Earlier it was stated that the hermeneutical process finds it completion in expository preaching. As the doctrine of the Trinity informed Calvin's dogmatics and his exegesis, so it informed his understanding of preaching (cf. Butin, 1995:58-60). Preaching as expositing God's Word, confirmed the trinitarian character of revelation in that the Father is the "beginning and fountain" of revelation, the Speaker of God's Word in Scripture; the Son is the divine Word spoken in Scripture, according to whom is "the ordered disposition of all things"; and the Spirit, to whom is assigned "the power and efficacy of that activity," is the divine enabler of the human reception and response to that Word (cf. 1.13.18). We may justly call this a trinitarian hermeneutics, or a trinitarian paradigm for hermeneutics. What is instructive, is that it offers a meaningful way through the current crisis of hermeneutics, which has since the Enlightenment located meaning first in the author, then in the text itself, and finally in the recipient of the text, with the end-result the loss of determinable meaning in divine communication. Vanhoozer (1998:456) remarks:

From a Christian perspective, God is first and foremost a communicative agent, one who relates to humankind through words and the Word. Indeed, God's very being is a self-communicative act that both constitutes and enacts the covenant of discourse: speaker (Father), Word (Son), and reception (Spirit) are all interrelated.

In this "trinitarian way" two important hermeneutical principles are guarded, that of authorial intention (the historical and epistemological aspect), and of authorial encounter (the personal and soteriological aspect). For, biblical hermeneutics is concerned not only with the fact that God has spoken, but with God speaking. The most important hermeneutical gift from God to his people is thus not only the unity and wholeness of his revelation to us, but his giving of himself in every step 
of the hermeneutical process. Preaching has a vital role to play in this self-impartation. As Calvin stated in his Commentary on John, 7:33: "As often as Christ calls us to the hope of salvation by the preaching of the gospel, he is present with us. For not without reason is the preaching of the gospel called Christ's descent to us". Parker (1992:23 f.) explains:

According to Calvin, then, preaching so to say 'borrows' its status of 'Word of God' from Scripture. It is the Word of God inasmuch as it delivers the Biblical message, which is God's message or Word. But 'God's Word' means, for Calvin, that which is spoken by God; not simply in its first giving but in its every repetition. ... If the teaching is faithful to Scripture, then it is God who is speaking, and that precisely because his teaching remains his teaching irrespective of the purveyor of the teaching.

Preaching is none other than the Triune God calling and summoning men. It is "a scene of divine activity, and of human activity drawn into the divine" (Parker, 1992:31f).

\subsection{A response of humility and conviction}

It follows that the human preacher is confronted with a unique challenge. As the Bible (and God through it), is not unable to "speak for itself" (in the mind of Calvin the Bible is intrinsically God's Word, not merely instrumentally; cf. 1.7-9), the preacher's challenge is not to speak for it, but to place himself in such a position under it, that his very style of relaying it models a response to the Word. Efficacy depends on fidelity, not expertise, and the authority of the pulpit lies not in human eloquence but in God speaking in Scripture. This places the minister in a very privileged position, and Calvin would have concurred with Packer that "the preacher, rather than the critical commentator or the academic theologian, is the true interpreter of Scripture" (1996:125).

Calvin's unique correlative view between Scripture and preaching must issue forth in a response of humility and conviction. Humility, because the interpreter or preacher must come before God's Speech as a receiver (and not a maker) of truth; conviction, because it is God speaking and he causes his own Speech to be heard (cf. Is. 55:11). The congregation must respond to the preaching of the Word in the same way. Calvin's message is strong. Those who refuse to "submit to the yoke of being taught by human word and ministry" are guilty of "blotting out the face of God which shines in his teaching" (4.1.5). Granting preacher and preaching the authority of God can be very dangerous, yet Calvin is convinced that through expository preaching, God himself will be the Shepherd of his flock. 


\section{Conclusion: a vision for preaching}

Isaiah the prophet was turned into a preacher by a vision. So too was Paul, who told Agrippa that he was not disobedient to the heavenly vision. In both cases of course the vision was a vision of God accompanied by the divine commissioning for service. In both cases the fulfilment of the mission involved hardship and opposition (Jenson, 1996:220).

It is often said that Calvin's influence on the city of Geneva, and subsequently the whole of Christendom, was marked by two factors; first, that his ministry was beset by constant opposition almost right to the end, and second, that the manner of his influence was essentially exercised by the preaching of God's Word. Both perseverance in trial and conviction in preaching must flow from a real encounter with God. The conflict Calvin encountered on the biblical doctrine of the Trinity had a profound impact on his theologising. His hermeneutics was affected by this doctrine along every phase, from exegesis to doctrine to preaching. Furthermore, that the Triune God had spoken and continued to speak was of singular importance to Calvin, because it was through his Speech that salvation came and saving knowledge of him was imparted.

Calvin would have agreed that

"... teachers and preachers in seminaries and churches must be people 'for whom the great issue is the knowledge of God', whatever their area of specialisation might be. Preachers and teachers who do not see this point and passionately hold to it are worse than useless: they are dangerous, because they are diverting" (Carson, 1996:489).

Calvin's theological perspective on hermeneutics ensured that the knowledge of God was secured throughout the interpretational process. As he reminded us so often, "to know God is man's chief end, and justifies his existence", and "even if a hundred lives were ours, this one aim would be sufficient for them all" (Commentary, Jeremiah 9:23f). To know God, is to know him as he has revealed and continues to reveal himself through his Speech, the magnificent and incomparable Triune Lord.

\section{Bibliography}

BEEKE, J.R. 1999. The Quest for Full Assurance: The Legacy of Calvin and His Successors. Carlisle : Banner of Truth.

BRAY, G. 1993. The Doctrine of God. Downers Grove : InterVarsity Press.

BRAY, G. 1996. Biblical Interpretation: Past and Present. Downers Grove : InterVarsity Press.

BUTIN, P.W. 1995. Revelation, Redemption and Response: Calvin's Trinitarian Understanding of the Divine-Human Relationship. New York : Oxford University Press. 
CALVIN, J. 1960. Institutes of the Christian Religion (1559). Library of Christian Classics, vols. 20-21, ed. J.T. McNeill, trans. F.L. Battles. Philadelphia : Westminster.

CALVIN, J. 1975. Institutes of the Christian Religion (1536). Trans. F.L. Battles. Grand Rapids : Eerdmans.

CALVIN, J. 1979. Calvin's Commentaries. Calvin Translation Society, 22 vols. Grand Rapids : Baker.

CALVIN, J. 1980. Letters of John Calvin: Selected from the Bonnet Edition. Carlisle : Banner of Truth.

CALVIN, J. 1997. Sermons on the Deity of Christ. Trans. L. Nixon (In AGES Digital Library. The Comprehensive John Calvin Collection. Old Paths Publications.)

CARSON, D.A. 1996. The Gagging of God: Christianity Confronts Pluralism. Grand Rapids : Zondervan.

CLARK, R.S. 1999. The Catholic-Calvinist Trinitarianism of Caspar Olevian. Westminster Theological Journal, 61(1):15-39.

CLOWNEY, E.P. 1961. Preaching and Biblical Theology. Phillipsburg : Presbyterian and Reformed Publishing.

DE GREEF, W. 1993. The Writings of John Calvin: An Introductory Guide. Trans. L.D. Bierma. Grand Rapids : Baker.

GAMBLE, R.C. 1988a. Calvin as Theologian and Exegete: Is there anything new? Calvin Theological Journal, 23(2):178-194.

GAMBLE, R.C. 1988b. Calvin's Theological Method: Word and Spirit: A Case Study. (In Schnucker, R.V., ed. Calviniana: Ideas and Influence of Jean Calvin. Kirksville : Sixteenth Century Essay \& Studies. p. 63-75.)

GANOCZY, A. 1989. Observations on Calvin's Trinitarian Doctrine of Grace. Trans. K. Crim. (In McKee, E.A. \& Armstrong, B.G., ed. Probing the Reformed Tradition: Historical Studies in Honour of Edward A. Dowey, Jr. Louisville : Westminster John Knox Press. p. 96-107.)

GEORGE, T. 1988. The Theology of the Reformers. Nashville : Broadman.

GREIDANUS, S. 1988. The Modern Preacher and the Ancient Text: Interpreting and Preaching Biblical Literature. Grand Rapids : Eerdmans.

HESSELINK, I.J. 1997. Calvin's First Catechism: A Commentary. Louisville : Westminster John Knox Press.

HOUSTON, J.M. 1996. Knowing God: The Transmission of Reformed Theology. (In Lewis, D. \& McGrath, A.E., ed. Doing Theology for the People of God: Studies in Honour of J I. Packer. Downers Grove : InterVarsity Press. p. 223-244.)

JENSON, P. 1996. A Vision for Preachers. (In Lewis, D. \& McGrath, A.E., ed. Doing Theology for the People of God: Studies in Honour of J.I. Packer. Downers Grove : InterVarsity Press. p. 207-221.)

LANE, T. 1991. Recent Calvin Literature: A Review Article. Themelios, 16(2):17-24.

LINTS, R. 1993. The Fabric of Theology: A Prolegomenon to Evangelical Theology. Grand Rapids : Eerdmans.

MCKEE, E.A. 1989. Exegesis, Theology, and Development in Calvin's Institutio: A Methodological Suggestion. (In McKee, E.A. \& Armstrong, B.G., ed. Probing the Reformed Tradition: Historical Studies in Honour of Edward A. Dowey, Jr. Louisville : Westminster John Knox Press. p. 154-172.)

MCGRATH, A.E. 1990. A Life of John Calvin: A Study in the Shaping of Western Culture. Oxford : Blackwell.

MCGRATH, A.E. 1993. Reformation Thought: An Introduction. Oxford : Blackwell.

MULLER, R.A. 1985. Dictionary of Latin and Greek Theological Terms: Drawn Principally from Protestant Scholastic Theology. Grand Rapids : Baker. 
MULLER, R.A. 1991. The Study of Theology: From Biblical Interpretation to Contemporary Formulation. Grand Rapids : Zondervan.

NEUSER, W.H. 1984. The Development of the Institutes, 1536 to 1559. (In John Calvin's Institutes His Opus Magnum: Proceedings of the Second South African Congress for Calvin Research. Potchefstroom : Institute for Reformational Studies. p. 33-54.)

PACKER, J.I. 1996. Truth and Power: The Place of Scripture in the Christian Life. Downers Grove : InterVarsity Press.

PARKER, T.H.L. 1971. Calvin's New Testament Commentaries. London : SCM.

PARKER, T.H.L. 1992. Calvin's Preaching. Louisville : Westminster John Knox Press.

PARKER, T.H.L. 1995. Calvin: An Introduction to Hhis Thought. Louisville : Westminster John Knox Press.

PARTEE, C. 1987. Calvin's Central Dogma Again. The Sixteenth Century Journal, XVIII(2):191-199.

ROTONDO, A. 1968. Calvin and the Italian Anti-Trinitarians. Trans. J. \& A. Tedeschi. St. Louis : Foundation for Reformation Research.

SILVA, M. 1994. The Case for Calvinistic Hermeneutics. (In Kaiser, W.C. \& Silva, M., ed. An Introduction to Biblical Hermeneutics. Grand Rapids : Zondervan. p. 251269.)

TORRANCE, T.F. 1994. The Doctrine of the Holy Trinity in Gregory Nazianzen and John Calvin. (In Trinitarian Perspectives. Edinburgh : Clark. p. 21-40.)

VANHOOZER, K.J. 1998. Is There a Meaning in this Text?: The Bible, the Reader and the Morality of Literary Knowledge. Leicester : Apollos.

WARFIELD, B.B. 1956. Calvin's Doctrine of the Trinity. (In Calvin and Augustine. Philadelphia : Presbyterian and Reformed Publishing. p. 189-284.)

WILLIAMS, S.N. 1995. Revelation and Reconciliation. Cambridge : Cambridge University Press.

\section{Key concepts:}

doctrine and hermeneutics; Calvin

doctrine and preaching; Calvin

John Calvin: theological hermeneutics

Trinity; doctrine of

\section{Kernbegrippe:}

Drie-eenheid

Johannes Calvyn: teologiese hermeneutiek

leerstelling en hermeneutiek; by Calvyn

leerstelling en prediking; by Calvyn 